\title{
EFFICIENCY ASSESSMENT OF IMPLEMENTATION OF THE MECHANISM OF INNOVATIVE RISK MANAGEMENT OF THE FAT AND OIL INDUSTRY IN UKRAINE
}

\author{
Yuliya Zhadan ${ }^{1}$ \\ ${ }^{1}$ Department of innovative entrepreneurship management and international economic relations, National Technical University «Kharkiv \\ Polytechnic Institute», Kharkiv, Ukraine \\ omsroot@kpi.kharkov.ua \\ ORCID http://orcid.org/0000-0002-3673-7552
}

ARTICLE INFO

Article history:

Received date 24.08.2020

Accepted date 06.10.2020

Published date 30.10.2020

Section:

Production \& Operations Management

DOI

$10.21303 / 2313-8416.2020 .001455$

KEYWORDS

risk

management

mechanism

efficiency

processing enterprise

fat and oil industry

\section{A BSTRACT}

Object of research: risk management processes of enterprises of the oil and fat industry in Ukraine.

Investigated problem: to assess the efficiency of the implementation of the mechanism of innovative risk management for enterprises of the oil and fat industry in Ukraine

Main scientific results: the paper proposes a scientific and methodological approach to quantifying the effectiveness of the implementation of the mechanism of innovative risk management (MIRM) of enterprises of the oil and fat industry in Ukraine, based on comparing the net present value before and after the MIRM implementation and consists of a number of successive interrelated stages, which include: comparative analysis and integrated assessment of unsystematic (financial, production, investment and other types) risks before and after the MIRM implementation at the enterprise; expert assessment of systematic risks that form the environment of the enterprise and can't be controlled; determination of the total risk value as an arithmetic weighted average non-systematic and systematic component for each type of risk; determination of discount rates taking into account risk before and after the MIRM implementation at the enterprise using the CAPM model (capital assets pricing model) for calculating and comparing the net present value before and after the MIRM implementation at the enterprise (NPV and NPV', respectively). Efficiency assessment of the implementation of the mechanism of innovative risk management (MIRM) was carried out on the example of eleven processing enterprises of the fat and oil industry in Ukraine.

The scope of practical use of research results: the risk management system of processing enterprises of the fat and oil industry in Ukraine, which should be the object of constant monitoring of the feasibility of implementation and assessment of the effectiveness of MIRM functioning by management and top management.

Innovative technological product: a scientific and methodological approach to quantifying the effectiveness of the implementation of the mechanism of innovative risk management for enterprises of the oil and fat industry in Ukraine, based on comparing the net present value before and after the MIRM implementation (NPV and NPV', respectively) using the CAPM model (capital assets pricing model) to determine the discount rates taking into account the risk before and after the MIRM implementation ( $\mathrm{d}$ and $\mathrm{d}$ ', respectively), which makes it possible to determine the expected amount of reduction in losses at the processing enterprises of the oil and fat industry of Ukraine from the implementation of a set of risk management measures and make informed management decisions on the appropriateness of their application.

Scope of application of the innovative technological product: processing enterprises of the oil and fat industry in Ukraine.

(C) The Author(s) 2020. This is an open access article under the CC BY license http://creativecommons.org/licenses/by/4.0).

\section{Introduction}

In modern conditions, the efficiency assessment of the implementation of the mechanism of innovative risk management of enterprises in the oil and fat industry in Ukraine is an urgent problem, the solution of which will ensure effective risk management of enterprises in the fat and oil industry. Modern enterprises operate in an uncertain market environment and strive for sus- 
tainable development. The relevance of the topic and the practical importance of scientific research influenced the choice of the topic of the article.

\section{1. The object of research}

The object of research is the processes of risk management of enterprises of the oil and fat industry in Ukraine.

\section{2. Analysis of publications and highlighting the unsolved part of the problem}

In the context of modern socio-economic development, the number of risk-forming factors that negatively affect the activities of the enterprise is growing rapidly. That is why the assessment of the effectiveness of the implementation of the risk management mechanism is one of the important conditions for the stable functioning of industrial enterprises.

The work [2] proposes an organizational and economic mechanism for managing internal risks of interaction between a corporation of industrial enterprises of railway transport, including the development of a strategy for managing internal risks of interaction at the level of corporate management and mechanisms for operational risk management at the level of corporation members, as well as comprehensive control through a monitoring system of the management process internal risks of interaction on the CEO part. The work [3] substantiates the need to improve the mechanism of risk management of entrepreneurial activity and identifies its main components: legal as a set of regulatory and formal documents on risk management of entrepreneurial activity; managerial, which is considered in the context of various enterprises in terms of size; organizational as a set of methods and ways of implementing the main stages of the business risk management process. The work [4] defines the place of the risk management mechanism in the enterprise management system, justifies the need for its formation and implementation, developed a risk management mechanism at an industrial enterprise, defines its main constituent elements and establishes their relationship.

Thus, the problem of forming and assessing the effectiveness of the implementation of the mechanism of innovative risk management of enterprises in the fat-and-oil industry of Ukraine today remains insufficiently disclosed and requires proper coverage as an important component of the enterprise management mechanism. Therefore, let's consider it necessary to focus on the study of assessing the effectiveness of the implementation of the mechanism of innovative risk management for enterprises of the oil and fat industry of Ukraine

To ensure sustainable economic development of any enterprise a necessary component of the enterprise management mechanism, along with the organizational and structural mechanism, quality management mechanisms, competitive advantages should be the mechanism of innovative risk management (MIRM) [5; 8]. The task of developing and implementing MIRM becomes even more urgent for objective reasons, which can include the policy of state control bodies, assess the degree of risk (Fig. 1).

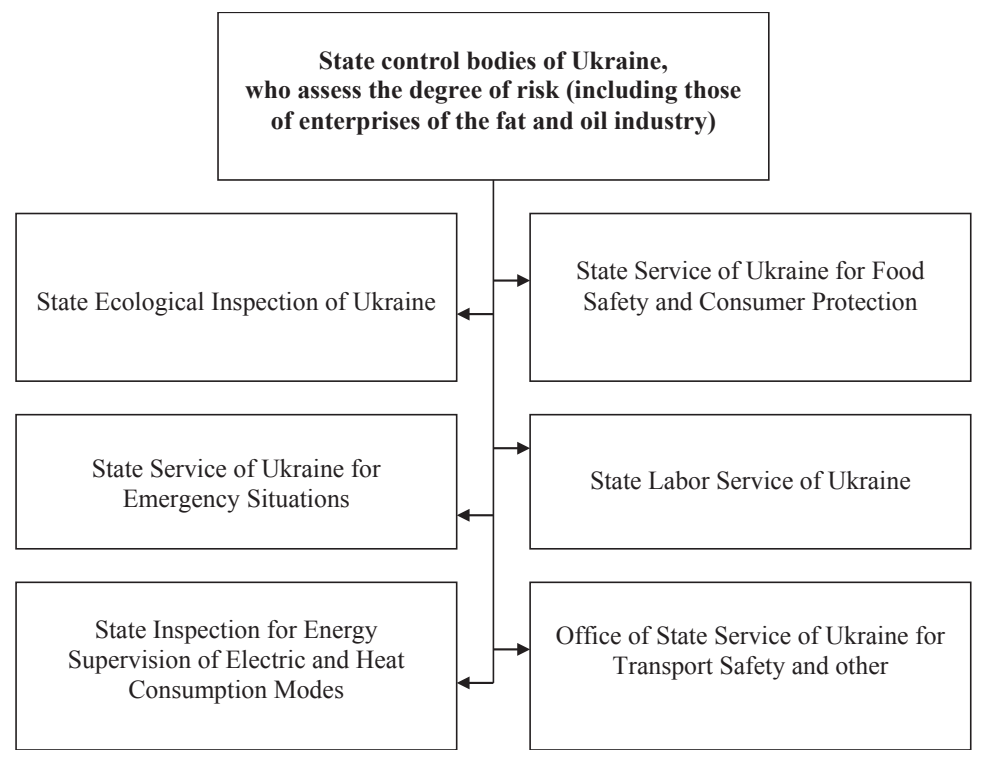

Fig. 1. The list of state control bodies that assess the risks of enterprises in the oil and fat industry of Ukraine 


\section{3. Method for solution of the problem}

Let's offer the following point of view on efficiency assessment assessing of the functioning of enterprises' MIRM in the fat and oil industry.

The actual threat of the emergence of enterprise risks leads to possible losses. Threats to the assets of the enterprise force the risk manager to use appropriate risk management methods in order to reduce possible losses to the enterprise. The set of factors proving the objective necessity of building risk management systems at a particular enterprise is not constant. In particular, this is due to the following prerequisites: the growing volatility of financial markets, periodic crises and shocks (including natural and man-made disasters, the threat of terrorist attacks), pressure from regulatory bodies, the need to improve risk management mechanisms [6].

The aim of research is to quantitatively assess the efficiency of the implementation of the mechanism of innovative risk management of enterprises in the oil and fat industry in Ukraine

\section{Materials and methods}

When deciding on the implementation of certain risk management measures, one should rely on the provision that the implementation of certain risk management measures is effective in conditions when the amount of potential damage to processing enterprises of the fat and oil industry exceeds the cost of measures to manage the accounted risks. Thus, one should strive to satisfy the following inequality:

$$
R \geq C
$$

where $R$ - the amount of potential damage if a risky event occurs (see the ratio $R=f\left(p, \vec{K}_{a c t}, \vec{K}_{n o r m}\right)$, (where $R$ - the level of possible losses; $p$ - the probability of an undesirable situation); $\vec{K}_{a c t}-$ the vector of actual (achieved) values of the features by which the risk is assessed; $\vec{K}_{\text {norm }}$ - the vector of normative values of the features by which the risk is assessed; $f$ - a function that connects the arguments $p, \vec{K}_{a c t}$, with the result $R$ ); $C$ - the integral cost of measures to implement risk management measures.

Calculation of the total cost of risk management measures requires not only summing up the cost of the corresponding resource in monetary or other form. It is necessary to index the cost of the alternative placement of each specific resource:

$$
C=\sum_{i=1}^{n}\left(C_{i} A_{i}\right) / \sum_{i=1}^{n} A_{i}
$$

where $C_{i}$ - the monetary value of the $i$-th risk management measure; $A_{i}$ - the cost of modern alternative investment of the $i$-th resource.

The next step is to calculate the expected amount of damage reduction $\Delta R$ when implementing the selected risk management measures:

$$
\Delta R=R-R^{\prime}
$$

where $R^{\prime}$ - the actual amount of damage after the application of risk management measures.

To determine the economic efficiency of risk management measures, the expected amount of damage reduction is correlated with the cost of risk management measures $C$ :

$$
Y=\Delta R-C
$$

Indicator $\mathrm{Y}$ characterizes the expected amount of loss reduction, taking into account the costs of implementing and financing risk management measures.

If the value of $\mathrm{Y}$ is negative, then it can be concluded that the measures to manage the risks of enterprises in the fat-and-oil industry of Ukraine are insufficiently effective. This can be interpreted in such a way that the cost of introducing and applying the selected risk management measures may not be compensated for by reducing the damage to enterprises of the fat and oil industry in Ukraine. In this case, a decision should be made on a thorough analysis and control of the financing costs of risk management activities. 
At the stage of choosing a strategy or a system of risk management measures, a certain economic efficiency function $G\left(Y_{1}, Y_{2}, \ldots, Y_{m}\right)$ is used. For its practical implementation, measures are selected with the maximum value of the economic efficiency indicator $\max \left\{G\left(Y_{1}, Y_{2}, \ldots, Y_{m}\right)\right\}$. Since the risk in a quantitative sense is a probabilistic value, deviations of the actual indicators from the calculated ones are possible. The magnitude of such a deviation largely depends on the accuracy of the calculations performed, the quality and reliability of the initial data. The result will also depend on the timeliness and completeness of the analysis to identify and assess risks.

For example, let's evaluate the efficiency of the risk management system of the Private Joint Stock Company with Foreign Investments Dnipro Oil Extraction Plant (PJSC FI “DOEP”), Ukraine.

The state point of view on the riskiness of the functioning of PJSC with FI "DOEP" is presented in Table 1.

\section{Table 1}

The assessment results of the riskiness of the activities of PJSC with FI "DOEP" by the State Inspection Services of Ukraine in 2018

\begin{tabular}{lc}
\hline \multicolumn{1}{c}{ PJSC with FI «DOEP» } & Risk \\
\hline State Ecological Inspection of Ukraine & HIGH \\
State Service of Ukraine for Emergency Situations & HIGH \\
State Service of Ukraine for Food Safety and Consumer Protection & HIGH \\
State Labor Service of Ukraine & HIGH
\end{tabular}

State Inspection for Energy Supervision of Electric and Heat Consumption Regimes in the Dnipropetrovsk Region AVERAGE

Office of State Service of Ukraine for Transport Safety in the Dnipropetrovsk region

AVERAGE

Source: calculated by the author according to [9]

Table 2 presents data for calculating the total cost of risk management activities.

Using formula (2), let's find that the total monetary value of the selected risk management measures $\mathrm{Ci}$ is 15,000 thousand UAH. The calculation of the cost of these activities is carried out on the basis of Table 2.

Table 2

Data for calculating the total cost of risk management activities

\begin{tabular}{cccc}
\hline Type of risk & $\mathbf{A i}$, thousand $\mathbf{U A H}^{*}$ & $\mathbf{C i}$, thousand $\mathbf{U A H}$ & $\mathbf{A i}^{*} \mathbf{C i}$ \\
\hline Industrial & 4000 & 5000 & 20000000 \\
Financial & 6000 & 5000 & 30000000 \\
Investment & 5000 & 4000 & 20000000 \\
Other risks & 1000 & 1000 & 1000000 \\
Sum & 16000 & 15000
\end{tabular}

Note: * the official rate of the national currency of Ukraine, the hryvnia (UAH) against foreign currencies as of September 16, 2020 (USD: 1 UAH=28.0556 USD; euro: $1 U A H=33.3441$ EUR). Source: https://bank.gov.ua/ua/markets/exchangerates?date $=16.09 .2020 \&$ period $=$ daily

Benefit in terms of alternative investment over the implementation of risk management measures C is UAH 1,000,000. (16,000,000-15,000,000 UAH). That is, this happens due to the manifestation of financial and investment risk, indicates the presence of more profitable alternative sources of investment, however, one should remember that there are high risks of loss of investment funds of enterprises, due to their investment in super-profitable business areas and the importance of developing and financing their own risk management systems of enterprises oil and fat industry of Ukraine. The enterprise should monitor these activities once a month, correct and control the reliability of risk assessment and the cost of implementing risk management activities. In the event 
of an increase in the level of financial and investment risks, the latter can be insured in insurance companies.

Under the conditions that $R=\mathrm{UAH} 17,000,000, A R^{\prime}=\mathrm{UAH} 15,000,000$. Then $\Delta R=17,000,000$ $-15,000,000=2,000,000 \mathrm{UAH}, Y=2,000,000-1,000,000=1,000,000 \mathrm{UAH}$.

In order to detail the assessment of the effectiveness of the mechanism of innovative risk management (MIRM), let's adapt the model proposed by R. Dodge [8]. Let's note that the risk that arises during the MIRM functioning is the result of two generalizing factors:

- the risk of significant deviations in the functioning of the enterprise;

- the risk that there are deviations in the functioning of the enterprise that were not detected by MIRM.

MIRM efficiency can be understood as the MIRM minimum acceptable risk, which allows the company to achieve its goals, adhere to the adopted strategy and minimize possible losses. Thus, it is proposed to calculate the total risk of MIRM $P_{\text {MIRM }}$ using the formula (5):

$$
P_{\text {MIRM }}=\sqrt{P_{s d} P_{n}}
$$

This model allows to obtain a criterion that describes the risk of an enterprise when assessing the MIRM effectiveness. If to single out the two considered risk factors as components, then this approach will allow to determine the permissible risks for each element of the risk management process, at a given level of risk. The approach of R. Dodge [8] does not allow one to obtain a quantitative expression of MIRM effectiveness, but indicates the ways to formalization. Let's point out that the most relevant now are models that, based on the results of the analysis, allow to quantify the effectiveness of the financial risk management system. As one of the methods for quantitatively assessing MIRM effectiveness, let's propose to use an approach that is based on the analysis of NPV in general for all areas of the enterprise, taking into account its change depending on the MIRM functioning.

In the course of its operation, an enterprise faces many threats. All risks can be divided into systematic and non-systematic. Non-systematic risks are understood as those risks, the impact of which the company can independently reduce by introducing a more effective management system. Let's consider the steps required to assess MIRM and which use the NPV factor. Let's start from the research of G. Kutergin [10], generalizing and developing it.

Stage 1. For non-systematic risks, the following analysis is proposed:

- first, financial risks are assessed in the MIRM absence at the enterprise Pi (initial risk);

- the value of each type of risk $P i$ ' is estimated after the MIRM implementation (final risk), which lead to a decrease in the integral risk, that is, the inequality $P i>P i$ ' must be fulfilled;

- carry out the calculation of the initial and final risk taking into account the weight coefficients using the formula (6):

$$
\begin{gathered}
P=P 1^{*} K 1+P 2 * K 2+P 3^{*} K 3+P 4 * K 4 ; \\
P^{\prime}=P 1^{\prime *} K 1+P 2^{*} K 2+P 3^{\prime *} K 3+P 4^{\prime *} K 4,
\end{gathered}
$$

where $K 1, K 2, K 3, K 4$ - weight coefficients.

The content of the components of formula (6), as well as the general structure of the assessment of non-systematic risks are shown in Table 3.

Table 3

General framework for assessing non-systematic risks

\begin{tabular}{ccccc}
\hline Type of risk & $\begin{array}{c}\text { Risk assessment in } \\
\text { the MIRM absence }\end{array}$ & Anti-risk procedures & $\begin{array}{c}\text { Risk assessment in } \\
\text { the MIRM presence }\end{array}$ & $\begin{array}{c}\text { Efficiency } \\
\text { condition }\end{array}$ \\
\hline Financial risk & $P 1$ & Procedure 1.1. Procedure 1.2. & $P 1^{\prime}$ \\
Production risk & $P 2$ & Procedure 2.1. Procedure 2.2. & $P 2^{\prime}$ \\
Investment risk & $P 3$ & Procedure 3.1. Procedure 3.2. & $P 3^{\prime}$ & $P i>P i$ \\
Other risks & $P 4$ & Procedure 4.1. Procedure 4.2. & $P 4$ & \\
Integral risk & $P$ & - & $P{ }^{\prime}$
\end{tabular}


Stage 2. Experts (responsible for identifying risks) assess the systematic risks (Rsyst), which form the environment for the operation of the enterprise and can't be controlled by it. It is generally accepted that systematic risks are determined by a variety of factors, which include macroeconomic, legal and political. All of them, to one degree or another, affect the functioning of the enterprise. It should be noted that in a crisis, underestimation of systematic risks can lead to significant losses and even bankruptcy.

Stage 3. The next step is to determine the overall assessment of financial risk $r$. The total risk is formed as a weighted sum of the non-systematic component of the financial risk $P$ and the systematic component of the financial risk Psyst. The following formula can be proposed to determine the overall financial risk:

$$
\begin{aligned}
& r=K_{p} * P+K_{p s y s t} * P_{s y s t} \\
& r^{\prime}=K_{p} * P^{\prime}+K_{p s y s t} * P_{s y s t},
\end{aligned}
$$

where $P$ - initial unsystematic risk; $P^{\prime}$ - final non-systematic risk; $K_{\mathrm{p}}$ - share of non-systematic risk; $K_{p s y s t}$ - proportion of systematic risk; $P_{\text {syst }}$ - systematic risk; $r$ - initial general financial risk; $r^{\prime}$ - final total financial risk.

It should be noted that $r^{\prime}-r=K_{p}\left(P^{\prime}-P\right)$.

Stage 4. Let's use for our purposes the net present value NPV. The general formula for calculating NPV is as follows

$$
N P V=-I+\sum\left(\left(C F_{i}\right) /(1+d)^{i}\right)
$$

where $N P V$ - net present value; $I$ - volume of investments; $C F_{i}-$ value of possible cash flows; $d-$ discount rate.

$N P V$ calculation is present in any investment process.

Stage 5. At this stage, let's calculate two discount rates: the first taking into account the risk in the MIRM absence, and the second - taking into account the fact that MIRM has been introduced and is functioning. To calculate the discount rate, let's use the CAPM (capital assets pricing model) model, which is used in the securities market. According to the CAPM concept, the discount rate $\mathrm{d}$ is calculated using the following formula:

$$
d=R f+\beta *\left(R_{m}-R_{f}\right),
$$

where $R f$ - risk-free rate of return; $\beta$ - coefficient that determines the change in the price of shares of an enterprise in comparison with the change in prices for shares for all enterprises of this market segment - risk coefficient; $R_{m}$ - the average market rate of return on the stock market; $\left(R_{m}-R_{f}\right)-$ market risk premium.

It should be noted that this coefficient is a measure of risk, and if to assume that the resulting risk analysis reflects the main risks, then the following calculation of the coefficient can be proposed using formula (6):

$$
\begin{aligned}
& \beta=r / 100+1 ; \\
& \beta^{\prime}=r^{\prime} / 100+1,
\end{aligned}
$$

where $r$ - the total risk obtained as a result of the analysis.

Stage 6. Let's calculate two net present values with and without MIRM, using the following formulas (11):

$$
\begin{gathered}
N P V=-I+\sum\left(\left(C F_{i}\right) /(1+d)^{i}\right) ; \\
N P V^{\prime}=-I+\sum\left(\left(C F_{i}\right) /\left(1+d^{\prime}\right)^{i}\right) .
\end{gathered}
$$

Stage 7. Let's find the efficiency of introducing the mechanism of innovative risk management as the difference between the flows $N P V^{\prime}$ and $N P V$. For this let's use the formula (12): 


$$
\text { MIRMeffect }=N P V^{\prime}-N P V
$$

\section{1. Experiments}

As a practical implementation of the above methodological approach to assessing the effectiveness of MIRM implementation based on the use of the NPV factor, let's perform the corresponding calculations using formulas (5)-(12) for eleven analyzed enterprises of the fat and oil industry. The results are shown in Tables 4, 5.

\section{Table 4}

Distribution of enterprises according to the criterion "Risk assessment according to the author's methodological approach" to the implementation of the mechanism of innovative risk management of enterprises of the oil and fat industry in Ukraine

\begin{tabular}{ccccccccccc}
\hline $\mathbf{N}$ & $\mathbf{P 1}$ & $\mathbf{K 1}$ & $\mathbf{P 2}$ & $\mathbf{K 2}$ & $\mathbf{P 3}$ & $\mathbf{K 3}$ & $\mathbf{P 4}$ & $\mathbf{K 4}$ & $\mathbf{P}$ \\
\hline 1 & 0.3557 & 0.05 & 0.8449 & 0.15 & 0.5753 & 0.4 & 0.7291 & 0.4 & 0.666 \\
2 & 0.9687 & 0.05 & 0.6701 & 0.15 & 0.489 & 0.4 & 0.9182 & 0.4 & 0.712 \\
3 & 0.8849 & 0.05 & 0.1962 & 0.15 & 0.4555 & 0.4 & 0.0662 & 0.4 & 0.282 \\
4 & 0.513 & 0.05 & 0.8309 & 0.15 & 0.0431 & 0.4 & 0.9227 & 0.4 & 0.537 \\
5 & 0.6341 & 0.05 & 0.0718 & 0.15 & 0.9019 & 0.4 & 0.6711 & 0.4 & 0.672 \\
6 & 0.3192 & 0.05 & 0.2686 & 0.15 & 0.4718 & 0.4 & 0.5761 & 0.4 & 0.475 \\
7 & 0.0708 & 0.05 & 0.2266 & 0.15 & 0.7004 & 0.4 & 0.9489 & 0.4 & 0.697 \\
8 & 0.2743 & 0.05 & 0.8364 & 0.15 & 0.7088 & 0.4 & 0.985 & 0.4 & 0.817 \\
9 & 0.143 & 0.05 & 0.9949 & 0.15 & 0.0053 & 0.4 & 0.3828 & 0.4 & 0.312 \\
10 & 0.3314 & 0.05 & 0.6176 & 0.15 & 0.8971 & 0.4 & 0.4696 & 0.4 & 0.656 \\
11 & 0.8971 & 0.05 & 0.6784 & 0.15 & 0.6785 & 0.4 & 0.3831 & 0.4 & 0.571
\end{tabular}

Source: calculated by the author

Table 5

Distribution of enterprises according to the criterion "Risk assessment according to the author's methodological approach" after the implementation of the mechanism of innovative risk management of enterprises of the fat and oil industry of Ukraine

\begin{tabular}{ccccccccccc}
\hline $\mathbf{N}$ & $\mathbf{P 1}$ & $\mathbf{K 1}$ & $\mathbf{P 2}$ & $\mathbf{K 2}$ & $\mathbf{P 3}$ & $\mathbf{K 3}$ & $\mathbf{P 4}$ & $\mathbf{K 4}$ & $\mathbf{P}$ \\
\hline 1 & 0.6432 & 0.05 & 0.911 & 0.15 & 0.0129 & 0.4 & 0.5564 & 0.4 & 0.397 \\
2 & 0.6579 & 0.05 & 0.9489 & 0.15 & 0.3408 & 0.4 & 0.2584 & 0.4 & 0.415 \\
3 & 0.3991 & 0.05 & 0.0539 & 0.15 & 0.3237 & 0.4 & 0.2715 & 0.4 & 0.266 \\
4 & 0.5567 & 0.05 & 0.4646 & 0.15 & 0.2047 & 0.4 & 0.6411 & 0.4 & 0.436 \\
5 & 0.6095 & 0.05 & 0.56 & 0.15 & 0.3678 & 0.4 & 0.7775 & 0.4 & 0.573 \\
6 & 0.2843 & 0.05 & 0.989 & 0.15 & 0.6355 & 0.4 & 0.8577 & 0.4 & 0.760 \\
7 & 0.9833 & 0.05 & 0.4492 & 0.15 & 0.6492 & 0.4 & 0.4661 & 0.4 & 0.563 \\
8 & 0.3818 & 0.05 & 0.1002 & 0.15 & 0.5618 & 0.4 & 0.5709 & 0.4 & 0.487 \\
9 & 0.1389 & 0.05 & 0.1049 & 0.15 & 0.1976 & 0.4 & 0.0145 & 0.4 & 0.108 \\
10 & 0.1781 & 0.05 & 0.4919 & 0.15 & 0.4857 & 0.4 & 0.2585 & 0.4 & 0.380 \\
11 & 0.6532 & 0.05 & 0.9442 & 0.15 & 0.2273 & 0.4 & 0.7341 & 0.4 & 0.559
\end{tabular}

Source: calculated by the author 


\section{Results}

Fig. 2 shows two groups of assessments of integral risks, calculated for two situations:

a) MIRM is absent (Row 1);

b) MIRM is implemented (Row 2).

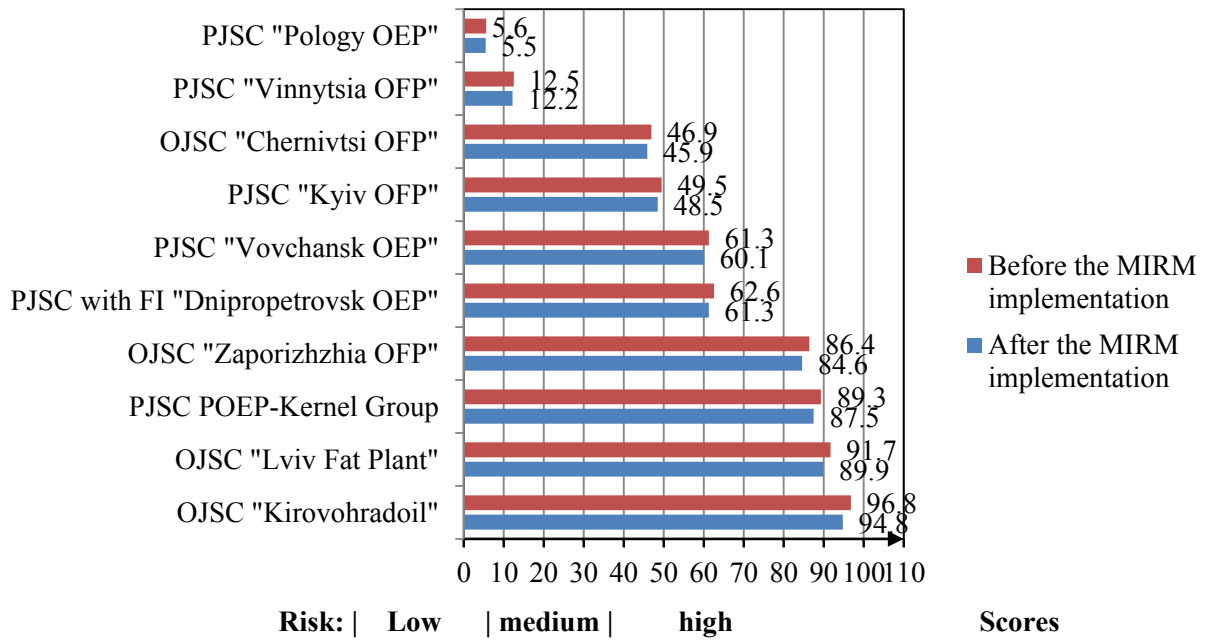

Fig. 2. Distribution of enterprises according to the criterion "Risk assessment according to the author's methodological approach", but taking into account the scale adopted in Ukraine.

Source: built by the author

Fig. 2 shows that the MIRM implementation leads to a decrease in the integral risk by $2-3 \%$.

\section{Discussion}

Based on the research carried out, as well as existing in the scientific economic literature $[7,9,10,11]$ approaches, it is possible to say that qualitative and quantitative methods are used to assess the effectiveness of the implementation of the risk management mechanism at the enterprise. Using qualitative methods based on the opinion of experts, a subjective assessment of the MIRM effectiveness is carried out. As a rule, qualitative methods are used for aggregated analysis and detailed qualitative assessment of MIRM. Quantitative methods allow combining previous subjective assessments of the results obtained, as well as increasing the effectiveness of the developed risk management measures.

To substantiate the effectiveness of financial risk management at oil service enterprises in [9], it is proposed to use generalizing quantitative (enterprise performance, productivity and overall efficiency) and qualitative (expediency and rationality, reliability and functional adaptability, compliance with standards and norms) criteria. The methodology proposed in [9] for the qualitative and quantitative assessment of financial risks for oilfield service enterprises takes into account the specifics of the industry and allows to measure the maximum level of harm from the occurrence of risk events and correlate it with the maximum allowable level of losses for the enterprise. Considering the effectiveness of financial risk management of an enterprise, the authors of [7] propose to evaluate it from two positions:

1) the presence in the financial management system of an enterprise of a certain organizational and managerial structure responsible for risk management, with appropriate functions and responsibility for their implementation;

2) on the basis of indicators - performance criteria, the achievement of which (compliance with which) will indicate the financial security of the enterprise, and therefore the correct organization of its risk management. As performance criteria, the standard values of the coefficients included in the generalizing indicators (risk of loss of the company's solvency, performance (profit dynamics), risk-return ratio, overall efficiency) are selected, which are compared with their actual values for a number of periods. 
However, these approaches do not make it possible to assess the lost benefits (as a rule, profit) by the enterprise before and after the implementation of risk management measures. That is why, more appropriate for assessing the economic consequences of risk management is a cost-based approach and an approach based on determining the net present value (NPV) of a project to implement a risk management mechanism. According to the cost approach [10], the economic effect of risk management will be characterized by the excess of the results of risk management over costs in the management process. The company's expenses for neutralizing the risk (mitigation) should not exceed the amount of financial losses from the risk, even with a high probability of a risk event. The approach based on the determination of the net present value [11] is used to assess the economic benefits of improving your own safety. In this case, various options for risk management measures are assessed according to the same principle as investment projects.

At the same time, the specifics of the activities of processing enterprises in the fat-andoil industry require the creation of their own mechanism for innovative risk management and assessment of the effectiveness of its implementation, the main stages and methodology of which were considered in this work.

The directions of further research of the author should be the search for ways to assess and cover the risks of processing enterprises of the oil and fat industry in Ukraine within the framework of modern international concepts.

\section{Conclusions}

The paper substantiates the need to improve the methodological approach to assessing the effectiveness of the implementation of the mechanism of innovative risk management of enterprises in the fat-and-oil industry of Ukraine.

The scientific and methodological approach to the quantitative assessment of the effectiveness of the implementation of the mechanism of innovative risk management of enterprises in the oil and fat industry of Ukraine has been improved, based on the comparison of the net present value before and after the MIRM implementation ( $N P V$ and $N P V^{\prime}$, respectively) using the CAPM model (capital assets pricing model) to determine the rates risk-adjusted discounting before and after MIRM implementation ( $d$ and d' respectively).

Efficiency assessment of the MIRM implementation was carried out on the example of eleven processing enterprises of the fat and oil industry in Ukraine, as a result of which it was found that the MIRM implementation at these enterprises helps to reduce the integral risk by $2-3 \%$.

\section{Acknowledgements}

The work was carried out within the framework of grant support for the research topic "Formation of an organizational and economic mechanism for managing industry and entrepreneurial risks" (state registration number DR 0118U007156), and its results found their practical embodiment in the activities of ROTEST LLC (contract No. 66774 dated 08.10. 2018), which made it possible to improve the quality of preparation and adoption of risk-oriented management decisions, avoid possible losses of material and financial resources, and improve the results of the company's financial and economic activities.

\section{References}

[1] Posokhov, I. M. (2015). Pobudova systemy ta rozrobka mekhanizmu upravlinnia vnutrishnimy ryzykamy vzaiemodii korporatsii promyslovykh pidpryiemstv zaliznychnoho transportu. Naukovyi visnyk Uzhhorodskoho universytetu. Seriia «Ekonomika», 2 (46), 213-220.

[2] Tiulenieva, Yu. V. (2010). Osnovy mekhanizmu upravlinnia ryzykamy pidpryiemnytskoi diialnosti. Problemy nauky, 1, 39-45.

[3] Tsvihun, T. V. (2017). Mekhanizm upravlinnia ryzykamy v systemi upravlinnia pidpryiemstvom. Naukovyi visnyk mizhnarodnoho humanitarnoho universytetu, 2, 9-13.

[4] Inspektsiinyi portal IAS DNK. Available at: https://inspections.gov.ua/ Last accessed: 21.04.2019

[5] Dodzh, R. (2018). Kratkoe rukovodstvo po standartam i normam audita. Moscow: Sirin, 224.

[6] Kutergina, G. V., Mordorskii, A. V. (2010). Analiz effektivnosti sistem upravleniia finansovymi riskami kommercheskoi organizatsii. Audit i finansovii analiz, 3. Available at: https://www.auditfin.com/fin/2010/3/03_08.pdf 
[7] Abasova, Kh. A. (2014). Metodika kompleksnoi otsenki upravleniia finansovymi riskami v organizatsiiakh nefteservisa. Upravlenie ekonomicheskimi sistemami, 10. Available at: http:/www.uecs.ru/finansi-i-kredit/item/3076-2014-10-13-12-26-27 Last accessed: 30.08 .2020

[8] Makarova, V. A. (2015). Analiz i otsenka ekonomicheskoi effektivnosti risk-menedzhmenta. Strategicheskie resheniia i risk menedzhment, 3 (90), 72-83. Available at: https://www.jsdrm.ru/jour/article/viewFile/479/461 Last accessed: 28.08.2020

[9] Muraveva, N. N., Udalova, N. N. (2015). Otsenka effektivnosti upravleniia finansovymi riskami v kommercheskikh organizatsiiakh. Ekonomika i biznes: teoriia i praktika, 4. Available at: https://cyberleninka.ru/article/n/otsenka-effektivnosti-upravleniya-finansovymi-riskami-v-kommercheskih-organizatsiyah Last accessed: 01.09.2020

[10] Posokhov, I. M. (2014). Teoretychni ta praktychni aspekty upravlinnia ryzykamy korporatsii. Kharkiv: PVPP «Slovo», 499.

[11] Barton, T., Shenkir, W., Walker, P. (2011). Improving Board Risk Oversight. Through Best Practices. Institute of Internal Auditors Research Foundation, 81.

[12] Minsky, S. (2018). To run an effective ERM program, you need the right risk metrics to know how to measure risk. Logic Manager. Available at: https://www.logicmanager.com/erm-software/2018/09/05/how-to-measure-your-enterprise-risk-managementeffectiveness/ Last accessed: 30.08 .2020 